\title{
Reinterrogar a ideologia para repensar o político: Lefort, leitor crítico de Marx
}

Réinterroger l'idéologie pour repenser le politique :

Lefort, lecteur critique de Marx

Martha Costa

Universidade de São Paulo | São Paulo | Brasil

\section{RESUMO}

Esta comunicação visa delinear um quadro geral das relações entre Lefort e Marx no que diz respeito ao debate acerca da origem, da função e das transformações da ideologia nas sociedades capitalistas modernas. Dentre a gama de temas que atestam a presença de Marx no pensamento de Lefort (como imaginário social, alienação, luta de classes, etc.), destacamos a centralidade da noção de ideologia, pois com ela está em jogo toda uma articulação de conceitos (história, classe, estatuto da divisão social, real e imaginário, etc.) que dão corpo à concepção política mais ampla do pensador francês. Sendo a ideologia analisada sob diferentes prismas ao longo de sua trajetória intelectual, buscamos nos deter no momento em que Lefort toma distância da concepção originária de Marx, formulada na Ideologia alemã, para alargar a compreensão da ideologia, atentar às suas novas figuras (ideologia totalitária, ideologia invisível) e, no mesmo movimento, reabrir as vias de acesso a um pensamento político. Seguindo e atando os fios do célebre ensaio de Lefort intitulado "Esboço de uma gênese da ideologia nas sociedades modernas" (I974), buscamos indicar os movimentos de continuidade

\section{RÉSUMÉ}

Notre objectif est de constituer un cadre des relations entre Lefort et Marx en ce qui concerne le débat sur l'origine, la fonction et les transformations de l'idéologie dans les societés modernes. Il $\mathrm{y}$ a plusieurs thèmes qui attestent la présence de Marx dans la pensée de Lefort, tels que l'imaginaire social, l'aliénation, la lutte de classe, etc. Parmi ces thèmes, on souligne la centralité de la notion de l'idéologie, parce que celle-ci est au coeur d'une articulation de concepts fondamentaux qui donne corps à la conception politique lefortienne au sens large du terme. Étant donné que, chez Lefort, l'idéologie est analysée sous différentes perspectives au cours de sa trajectoire intellectuelle, nous choisirons celle-ci qui met en scène les distances prises par Lefort par rapport au paradigme ouvert par Marx dans L'idéologie allemande. Ce faisant, Lefort vise élaborer une nouvelle compréhension de l'idéologie, discerner ses nouvelles figures (idéologie totalitaire, idéologie invisible) et, du même coup, ouvrir un nouvel accès à la pensée du politique. En suivrant les mouvements de l'article "Esquisse d'une génèse de l'idéologie dans les societés modernes " (I974), on indiquera les continuités et les éloigne- 
e afastamento realizados por ele com relação ao paradigma de Marx. Pelas novas referências para pensar as açōes da ideologia - encobrir a divisão social, desarmar os efeitos do conflito e da indeterminação - encena-se, pois, a crítica lefortiana ao naturalismo de Marx e à sua oposição bruta entre produção e representação, ou ainda, entre imaginário e real. O filósofo francês acrescenta ainda uma nova componente à discussão - o simbólico, como instância distinta à da ideologia — afastando a referência da ideologia a um fundamento exclusivamente econômico e promovendo a reabilitação do político, não mais reduzido, por princípio, ao domínio da mistificação.

\section{PALAVRAS-CHAVE}

Ideologia; Divisão social; Imaginário; Simbólico. ments que Lefort élabore en vue du paradigme de Marx. À partir des nouvelles références pour penser les actions de l'idéologie - couvrir la division sociale, désamorcer les effets du conflit et de l'indétermination - est mise en scène la critique lefortienne au naturalisme de Marx et à son opposition brute entre production et représentation, ou encore, entre le réel et l'imaginaire. Le philosophe français ajoute encore une nouvelle composante à la discussion - le symbolique, en tant qu'un domaine distinct de l’idéologie et, par là, il éloigne la référence de l'idéologie à un fondement exclusivement économique et promeut la réhabilitation du politique, ne plus réduit, par principe, au domaine de la mystification.

\section{MOTS CLEFS}

Idéologie ; Division sociale ; Imaginaire ; Symbolique.

Sabe-se que a reflexão sobre a ideologia é um tema estruturante do pensamento de Lefort e objeto de várias retomadas ao longo de sua trajetória intelectual, no sentido de compreender a origem, o funcionamento e as transformaçóes do discurso ideológico nas sociedades modernas. ${ }^{\mathrm{I}}$ A persistência dessa reflexão, aliás, é um dos signos mais visíveis da tensa relação marcada pela filiação e pelo afastamento que Lefort manteve com as concepções clássicas de Marx. Contudo, nem sempre os intérpretes da obra lefortiana ressaltam a centralidade dessa discussão ou comparam empréstimos e distâncias que o pensador francês toma de Marx; ainda mais notável, o comentário dominante quase não atenta às implicações que estão em jogo nesse embate para a elaboração da concepção geral do político em Lefort. ${ }^{2}$

I Cf. Lefort, Claude. "Esboço de uma gênese da ideologia nas sociedades modernas". In As formas da história: ensaios de antropologia política. São Paulo: Brasiliense, I979a, pp. 245-345. Trata-se, certamente, do ensaio mais esclarecedor, no qual o pensador francês elabora um balanço crítico da definição marxiana de ideologia e apresenta as balizas de sua própria concepção.

2 Temos em mente obras como Passion du politique : la pensée de Claude Lefort de Hugues Poltiers, e The philosophy of Claude Lefort de Bernard Flynn, nas quais a questão da ideologia é tratada sem o destaque merecido: ou não é abordada de maneira detida ou não tem suas consequências devidamente enfatizadas. 
Reinterrogar a ideologia implica a necessidade de relacionar as posições de Lefort frente ao paradigma inaugurado por Marx, que cunhou o sentido original e crítico que a noção de ideologia passa a ter para designar, nas formações sociais capitalistas, a lógica das ideias dominantes a serviço do ocultamento dos conflitos de classe e da legitimação das divisões sociais. ${ }^{3}$ Não vamos aqui, evidentemente, recobrir toda a extensão das relações de Lefort com o marxismo e a obra de Marx, que datam desde a juventude militante-trotskista do pensador francês. Basta dizer que nas décadas de 1940 e 1950, Lefort se voltava ao pensador alemão com o objetivo preciso de restituir o sentido autêntico e crítico da obra de Marx frente à degradação do debate marxista da época, flagrante no uso dos conceitos-chave de Marx para sustentar, na teoria e na prática, as ações do partido comunista em sua tarefa de justificar a formação da burocracia soviética, a nova divisão social entre executores e dirigentes e o funcionamento totalitário do regime stalinista. Mantendo-se numa posição à esquerda do campo intelectual, Lefort operava uma crítica do marxismo ortodoxo a partir da letra original de Marx, no intuito de restituir o sentido autêntico da classe proletária e de sua obra revolucionária, de tal modo que o socialismo se recolocasse como regime da liberdade, no qual a positivação do poder proletário efetivamente tivesse lugar. No nível teórico, tal empreitada passava por redefinir a subjetividade do proletariado enquanto práxis revolucionária, a fim de tornar dispensável a mediação do Partido, que se impunha como direção e consciência da classe proletária, submetendo-a uma nova modalidade de dominação. ${ }^{4}$ Deixando essa importante discussão de lado,

3 Cumpre ressaltar que, nesse diálogo crítico com Marx acerca da compreensão da ideologia, Lefort toma como alvo a argumentação do pensador alemão desenvolvida, sobretudo, na Ideologia Alemã.

4 Nesse primeiro momento do percurso intelectual de Lefort, a crítica à ideologia se insere no horizonte mais amplo da crítica ao novo sistema de dominação erigido na URss. A ideologia atuante nesse regime destina-se a encobrir e a legitimar, a um só tempo, a nova dominação em curso iniciada com a formação de uma nova classe dominante, a burocracia, e a apropriação do aparelho de Estado por essa camada dirigente. Para que isso acontecesse, a classe operária foi alijada do controle do processo produtivo e impedida de positivar o seu poder real na sociedade, em suma, foi reduzida à condição de mera executante. Os alicerces ideológicos do novo regime, necessários para ocultar a natureza burocrática de um Estado que se apresentava sob a imagem de um Estado do proletariado e para o proletariado, mostram-se num conjunto preciso de representações (a necessidade e a missão do Partido como consciência e direção da classe operária, o sacrifício histórico das gerações presentes para a construção do socialismo, a negação da divisão social, o ideal da socialização acabada, a participação no empreendimento coletivo, a dissolução do eu no "Nós" comunista, etc.) e se efetivam graças à ação de uma instituição central para o advento e a manutenção do regime stalinista: o Partido — máquina de modelação de corpos, como dirá Lefort. Em outras palavras, a ideologia operante nesse contexto não é mero discurso, mas se desvenda, sobretudo, como controle do processo de socialização dos agentes, comandado pelo partido comunista enquanto instância que detém as rédeas da produção da nova identidade social e cuja ação orienta-se para tornar efetivo aquele 
na qual a crítica de Lefort à ideologia se elaborava, como afirma Abensour, numa perspectiva mais interna ao marxismo ${ }^{5}$, vamos aqui nos ater a outro momento das relações entre Lefort e Marx, a saber, o início dos anos 1970, quando, sob os efeitos da reflexão acumulada sobre o totalitarismo e do longo estudo acerca da obra maquiaveliana, as relações de Lefort com as concepções de Marx passam a irromper na cena intelectual de uma perspectiva crítica. Crítica não no sentido de recusa ou ruptura completa do legado marxiano, mas de afastamento ou ultrapassagem de certos limites que Lefort passa a identificar no pensamento de Marx.

Nesse sentido, mais do que retroceder a um ponto de vista que esvaziaria de relevância os conceitos-chave que o marxismo nos legou (luta de classes, ideologia, imaginário social, exploração, fetichismo, etc.), Lefort almejava adentrar domínios aos quais o pensamento de Marx não dava passagem, por exemplo, a consideração da dimensão simbólica e libertária dos direitos do homem, a natureza do poder nas sociedades modernas e, principalmente, a desvinculação do regime democrático de sua definição liberal enquanto regime da lei e da ordem - definição, aliás, que o próprio marxismo havia colaborado para estabelecer ao fazer a crítica da democracia moderna enquanto regime da expressão política burguesa. Confrontar essas concepções era, então, um ato fundamental para reelaborar uma concepção de democracia enquanto regime da desincorporação do social, do poder enquanto lugar vazio, marcado pela ausência de fundamento último, inaugurado com a demolição dos "marcos de certeza", ou ainda, um regime que instaura por toda a extensão do social a legitimidade do conflito e do questionamento acerca da legitimidade, reconhecendo o estatuto originário da divisão social e, sobretudo, um regime que institui uma dinâmica ininterrupta de criação de direitos.

Ora, de que maneira a reinterrogação acerca da ideologia no cenário dos anos 70 poderia se vincular a esse projeto mais amplo de reabilitação do político e de um novo sentido para a democracia moderna? Mais do que se envolver numa querela teórica, ao se lançar nesse trabalho de reinterpretação, Lefort busca ultrapassar aquilo que ele designa os limites da análise de Marx, delineando uma concepção de ideologia que, ao mesmo tempo, não desconheça e não se confunda com a dimensão simbólica da sociedade, que não despreze os princípios políticos constitutivos da experiência moderna e não reduza o poder ao estatuto de coisa

imaginário e obter o assentimento dos sujeitos ao novo regime, operando por meio de uma lógica da identificação sem a qual o regime não subsiste: identificação da classe ao Partido, do indivíduo à Sociedade, do particular ao Universal, do presente à História. Essas diretrizes que apontamos aqui são amplamente desenvolvidas no conjunto de artigos que Lefort escreveu entre 1948 e 1963 e compôs o livro Éléments d'une critique de la bureaucratie, em I97I. 
empírica, mero produto social, em suma, instrumento de dominação da classe burguesa. Dentre tantas mudanças que sua reinterpretação da ideologia engendra, podemos enfatizar a tentativa lefortiana para restabelecer a eficácia do simbólico e redefinir o estatuto do poder, a fim de reabrir novas brechas e possibilidades históricas de luta e resistência contra a dominação. Para refazer o caminho dessa conclusão geral cuja enunciação já foi aqui adiantada, proponho uma análise esquemática que assinale a maneira como Lefort interpreta Marx e quais distâncias ele toma frente ao pensador alemão.

Segundo Lefort, o núcleo da análise da ideologia, em Marx, é a sua concepção de divisão social e modo de produção, ou seja, Marx não concebe a ideologia apenas como discurso de justificação ou conjunto das expressões ideais de uma classe específica - a burguesia —, mas vincula a ideologia à divisão fundadora da sociedade capitalista: a divisão capital-trabalho. Lefort ressalta essa abordagem própria a Marx, que toma a ideologia como um efeito necessário da maneira como a sociedade organiza sua atividade produtiva, como opera a divisão do trabalho e distribui a propriedade. Nesse sentido, o surgimento da ideologia mostra-se vinculado a duas espécies de divisão que, no fundo, se encontram ligadas: a primeira é a divisão/separação entre trabalho material e espiritual, o que marca o desprendimento e a fuga da consciência em relação ao mundo da práxis e a produção de filosofia, moral, direito, religião, de caráter puro e universal, sem vínculo com a realidade efetiva - como já indicavam as análises do jovem Marx na Ideologia Alemã. Mas, sobretudo, conforme a análise de Marx avança e se prende às especificidades históricas, a ideologia passa a ser concebida enquanto fenômeno específico do modo de produção capitalista, vinculado à divisão social capital-trabalho e expresso na divisão empírica das classes sociais em luta. Nascida dessa divisão fundamental sob o capitalismo, a ideologia é a ação que o imaginário social realiza para ocultar e/ou legitimar as divisōes e contradições dessa formação social. ${ }^{6}$ Assim, a ideologia pode ser apreendida, num primeiro sentido, como o conjunto das ideias dominantes de uma estrutura social capitalista ou, valendo-me das palavras originais de Marx, ela é "a expressão ideal das relaçôes materiais dominantes, são as relações materiais dominantes apreendidas como ideias; portanto, são a expressão das relações que fazem de uma classe a classe dominante, são as ideias de sua dominação" (Marx; Engels, 2007, p. 47).

É preciso ainda lembrar que a ideologia é analisada por Marx, seja na Ideologia Alemã ou em obras de maturidade, a partir da oposição real-imaginário ou, como

6 Por exemplo, a ideologia do dom e do mérito individual como narrativas burguesas que justificam desigualdades no espaço social apagando a referência histórica aos processos de aculturação a partir dos quais cada classe social parte e que explicam, em larga medida, as diferenças de êxito ou fracasso entre os agentes. 
dirá Lefort, a partir da "oposição bruta entre produção e representação". O que é o real, em Marx? O real é construído pela atividade humana material, empírica e histórica, não pelas ideias de caráter universal e transcendente, como julgava a tradição idealista alemã contra a qual Marx argumentava; poderíamos dizer, sob outro ângulo, que possui estatuto de realidade aquilo que se acha vinculado ao processo de produção e criação de valor; real é aquilo que se liga à base efetiva da história, à materialidade e à produtividade das relações humanas e sociais. Em contraposição a essa noção de real, que baliza as análises de Marx, a ideologia é sempre posta do lado da fantasia e da imaginação. Ou ainda, a ideologia é caracterizada como reflexo, como instância secundária que reflete de modo invertido a dimensão efetivamente real de uma sociedade. Além de reflexo, a ideologia é caracterizada pela operação de falseamento e/ou ocultamento do real. É assim, por exemplo, que as ideias universais de Igualdade e Liberdade, na relação contratual que vincula a mão de obra assalariada ao capitalista, por exemplo, escamoteiam a desigualdade real entre essas duas figuras: o capitalista e o trabalhador. Agindo como um véu, tais ideias de cunho universal e abstrato, portanto ideológico, escondem a diversidade empírica e real das experiências de vida para o trabalhador e para o capitalista, ocultam que cada ideia tem uma tradução prática diferente de acordo com a posição de classe que cada sujeito ocupa na estrutura social burguesa.

Contudo, a compreensão da ideologia, em Marx, não se encerra nessa primeira abordagem. Num outro sentido, é possível afirmar que, sob a égide de funcionamento da ideologia, a forma mercadoria, no seu modo imediato de aparição na esfera de circulação, escamoteia todo o processo de produção e formação do valor a partir da exploração de mais valia (como, aliás, mostra o Livro I do Capital). Seja a ideologia apreendida sob a forma de discurso ou ideologia em ato, enquanto a forma própria pela qual a sociedade aparece e é percebida pelos sujeitos - o que une esses dois sentidos da ideologia é a unidade de sua tarefa, qual seja, negar ou ocultar as divisões e contradições sociais, impedindo a revolução do modo de produção capitalista e sua passagem a outra forma de sociedade. Em suma, a ideologia é a tarefa conservadora que o imaginário social assume para bloquear o desdobramento da contradição da sociedade capitalista pelo acirramento da luta de classes, impedindo a demolição prática das relações sociais reais que estão em sua base. No entanto, trabalhando a partir da oposição entre real e imaginário, Marx tornou o imaginário uma categoria altamente abrangente e elástica, capaz de recobrir mesmo aquilo que é da ordem do sistema de significados e sentidos, ou seja, os valores, princípios e referências que formariam uma espécie de camada simbólica na sociedade; em Marx, os contornos do imaginário se expandem em demasia absorvendo tudo o que constitui a dimensão dos símbolos políticos e 
coloca nela o selo da falsidade e da dissimulação. ${ }^{7}$

Ao proceder desse modo, Marx deixaria sobressair, segundo Lefort, o paralelo entre o ideológico e o político. Ou melhor, Marx mostraria que, numa sociedade de classes, o ideológico segue os passos da política e, mesmo, confunde-se com ele. Ancorado na crítica que endereça à figura do Estado moderno, Marx estende as características da dominação política à expressão ideal da dominação, que recebe o nome de ideologia. Assim como o Estado se afigura como poder separado que transcende o social para representar a universalidade da lei, assegurando-se do direito à coerção física, a ideologia segue esse movimento rumo à transcendência e à generalização ao se constituir

Como um domínio separado - [que] compõe um mundo das ideias onde uma essência do social se encontra afigurada, [onde] as oposições de toda ordem [são] transfiguradas em determinação do universal, [e] a dominação convertida em expressão da lei. É evidente a afinidade entre o político e o ideológico: assim como o poder se separa de uma sociedade dilacerada de ponta a ponta para encarnar a generalidade da lei e exercer a coerção física - transpondo e disfarçando ao mesmo tempo a dominação de classe - também o discurso ideológico se separa de todas as formas da prática social para encarnar a generalidade do saber e exercer a coerção da persuasão - transpondo e disfarçando ao mesmo tempo em ideia o fato da dominação (Lefort, 1979a, p. 299).

Essa identificação do ideológico com o político, em Marx, (tal como se deixa apreender na sua crítica à figura do Estado e dos direitos do homem, respectivamente, na Crítica da filosofia do direito de Hegel e n'A questão judaica) se mostra problemática para Lefort, no interior de um horizonte de questôes políticas. De acordo com a perspectiva de Marx, são as relações de produção que, em última instância, configuram o núcleo de determinação do real e, por oposição, configuram também aquilo que é da ordem do reflexo invertido e da falsificação da realidade, isto é, da ideologia: direito, moral, filosofia, religião, etc. Lefort não aceita essa sobredeterminação dos polos da Lei, do Saber e do Poder pelas relações materiais de produção. Adiantando a argumentação, digamos, de maneira simplificada, que, para Lefort, é o político que institui o social e não o social que põe o político; nesse sentido, a ideologia responde por uma parte da obra que o imaginário social executa ao encobrir seus conflitos e divisões com um discurso que visa determinar o movimento de instituição do social, mas ela não mina e não se confunde com a dimensão simbólica do social, constituída pelo conjunto de

7 Por exemplo, a desqualificação teórica que Marx faz dos direitos do homem na Questão judaica. 
significantes, valores e ideias que uma sociedade institui para se tornar inteligível a si mesma, tornando inteligíveis suas açôes históricas e dotando-lhes de sentido.

Sem entrar agora no detalhe da dimensão simbólica do social, voltemos a Marx. Se o que está na base da dominação real são as relações materiais de produção e não propriamente a dominação das ideias, regras e valores burgueses, não deve surpreender o encaminhamento final das análises de Marx, que consiste na exortação de uma transformação prática do estado de coisas que torna real não apenas o mascaramento da realidade operado pela ideologia, mas outros fenômenos como a alienação, o fetichismo e a exploração. A essa transformação prática radical dos fundamentos de um modo de produção Marx chama de revolução. Assim, a crítica à ideologia culmina numa reflexão sobre a revolução comunista pela classe trabalhadora. Tal desfecho revela-se como a única maneira efetiva de transformar o estado atual das coisas, a única via, portanto, de modificar a consciência e as expressões espirituais dominantes no âmbito da filosofia, do direito, da religião, da moral. Trata-se, com efeito, de um desfecho coerente quando recuperamos a lembrança dos primeiros passos da reflexão marxiana, que faziam das ações reais - e não dos atos de pensamento - o motor das transformações históricas e, portanto, a condição de possibilidade de superação da ideologia. ${ }^{8}$

Esboçado esse quadro geral, cumpre interrogar de que modo Lefort se move no terreno preparado por Marx. A primeira mudança que Lefort introduz é na maneira de conceber a forma de sociedade na qual a ideologia surge. Para Lefort, a ideologia é um fenômeno típico daquilo que ele designa como sociedade moderna, assim como Marx atava a origem da ideologia à sociedade capitalista. Se é verdade que ambas — sociedade moderna e sociedade capitalista — possuem pontos de contato e apontam para a historicidade específica de uma nova forma social, em contraste com formas pré-modernas, a escolha de Lefort pelo termo sociedade moderna indica que, na sua análise, a prevalência não será posta na noção de modo de produção, mas no movimento de instituição do social e na posição do poder nas sociedades democráticas modernas.

Nesse sentido, Lefort nos sugere outro ponto de partida para a análise da origem da ideologia. Essa origem não pode ser apreendida como ponto fixo localizável tão somente no tempo cronológico, na medida em que se mostra consti-

8 Ao delinear os aspectos da concepção materialista da história, Marx afirma que ela busca explicar "as formaçōes ideais a partir da práxis material e chegar, com isso, ao resultado de que todas as formas e [todos os] produtos da consciência não podem ser dissolvidos por obra da crítica espiritual, por sua dissolução na 'autoconsciência' ou sua transformação em 'fantasma', 'espectro', 'visões', etc., mas apenas pela demolição prática das relaçôes sociais reais [realen] de onde provêm essas enganaçôes idealistas; não é a crítica, mas a revolução a força motriz da história e também da religião, da filosofia e de toda forma de vida”. (Marx; Engels, 2007, p. 43, grifos nossos). 
tuída pela confluência de vários fios de acontecimentos que se entrecruzam para inaugurar a modernidade política. ${ }^{9}$ Dentre eles, destaca-se a produção política do humanismo cívico florentino, que elaborou, pela primeira vez, a emergência de um discurso propriamente político concomitante à nova experiência da instituição do social, discurso que, ao ganhar autonomia, permitia, no mesmo movimento, a emergência da ideologia. ${ }^{\text {Io }}$ Se no plano do discurso político as raízes da modernidade remontam ao humanismo cívico, o advento da ideologia é marcado, em sentido forte para Lefort, no âmbito de formaçôes sociais nas quais o lugar do poder é um lugar vazio, não consubstancial ao corpo do governante. Segundo Lefort, para que a modernidade política fosse instaurada, foi preciso que o corpo do governante não mais se afigurasse como um duplo, simultaneamente natural

9 É importante indicar a oposição constante que norteia o pensamento de Lefort: a oposição entre pré-modernidade e modernidade, tão bem captada por Bernard Flynn (Cf. La philosophie politique de Claude Lefort, Parte II "Lefort et la prémodernité", pp. I3I-I87). A pré-modernidade desdobra-se em duas direçóes, pois Lefort trabalha com uma noção de pré-modernidade não somente restrita ao Ancien Régime, mas traz para o seu horizonte a referência de estudos antropológicos que lidam com as sociedades ditas "sem história", para compreender, por oposição, o tipo de dispositivo simbólico ali vigente bem como seus efeitos. Tendo isso em vista, não podemos falar em ideologia em sociedades ditas selvagens ou em sociedades nas quais a natureza do poder é mítica ou religiosa. Em tais sociedades, como não há separação entre o lugar da lei, do saber e do poder, aquilo que se entende por real já está definido de antemão pela palavra (mítica ou religiosa), e o dispositivo simbólico nelas atuante age no sentido de petrificar a compreensão do real e a impedir que surja a distinção entre o real e o imaginário. Dessa maneira, compreendese porque o nascimento da ideologia vincula-se à emergência do campo social em sua autonomia. Somente quando o espaço social se institui rompendo com a referência a um lugar-outro, de natureza mítica ou religiosa, que podemos apreender, concomitantemente a esse processo, o advento da ideologia como trabalho do imaginário para recobrir, dissimular e deter o curso dessa instituição.

IO A ideologia, que busca se passar como uma forma de saber, deve ser compreendida em relação ao polo cultural de produção dos saberes que caracteriza uma sociedade. A capacidade do saber em se diferenciar é uma conquista que se mostra na formação do Estado moderno, com a dissolução das monarquias absolutistas e a destruição do paradigma do corpo do rei. Tal experiência, que se manifesta na época moderna, Lefort faz remontar ao Renascimento. Em sua visão, o humanismo cívico florentino colaborou para produzir uma representação da política liberada da transcendência, representação que supunha a elaboração de um discurso propriamente político, antes inexistente, posto que o social não tinha autonomia, isto é, não aparecia a si como social. Costurando esses fios conceituais e históricos, Lefort afirma que "os traços do Estado moderno só se fixam num sistema no qual o saber tem a experiência de sua diferenciação, o saber tem nele mesmo a experiência da alteridade (no lugar em que a palavra se ordena sob o polo exterior do outro) - acontecimento cujas primícias foram postas pelo humanismo na época do Renascimento" (Lefort, I979a, p. 302. Cf. também nesse mesmo livro o ensaio "O nascimento da ideologia e do humanismo", no qual Lefort esclarece de que maneira a conquista inédita de autonomia do discurso político durante o Renascimento italiano (especificamente, o humanismo cívico florentino dos séculos XV e XVI) traz em sua anatomia a virtualidade da produção do discurso ideológico. 
e divino, mortal e imortal, que, por sua posição intermediária, concentrava em si não apenas a unidade e a identidade da comunidade política, mas os princípios de sua geração e ordenação. A experiência do poder como lugar vazio também supõe que ele deixe de subordinar e concentrar em si as esferas da Lei e do Saber. Ou seja, supõe-se que, de direito, a produção da Lei e do Saber desfrutem de uma exterioridade face ao Poder, que não se confundam com as determinaçôes impostas pelo Poder e que possam gozar de um direito à diferenciação. Em outras palavras, a produção da ideologia é um fenômeno moderno, que vem ocupar o lugar deixado pelo esvaziamento das formas transcendentes de explicação do mundo como o mito a religião, que forneciam o fundamento, o princípio de inteligibilidade e de justificação da ordenação social e do funcionamento do poder. A instância transcendente era o fundamento de onde provinham a legitimidade e a garantia do poder, instância de onde emanava o saber geral que ordenava a comunidade política e respondia às suas questóes. Quando o poder se torna desvinculado do corpo do governante, não mais referido a Deus, à Natureza ou à Razão, mas se mostra suspenso ao conflito das vontades e na dependência de um campo social autônomo, é que a ideologia pode se produzir na sociedade histórica como fenômeno que visa conduzir a indeterminação do social à sua determinação, erigindo-se como discurso de certeza que busca minar a interrogação e o debate.

O importante, assim, é frisar que a ideologia opera a partir e sobre a instituição do social. Nesse momento, o discurso social ainda está latente, é um discurso propriamente instituinte, que busca tornar visíveis os valores pelos quais a sociedade se orienta. No momento em que o social conquista autonomia, podendo tomar distância face ao poder, de modo a desdobrar uma infinidade de discursos sociais que reivindicam um direito à sua diferenciação (discurso econômico, discurso político, discurso estético, discurso pedagógico), a ideologia irrompe como uma linguagem de segunda potência, que segue os passos do discurso instituinte, buscando conferir a essa experiência social um saber geral e determinado capaz de deter o processo de indeterminação que caracteriza a instituição do social.

O momento de instituição do social é, portanto, inseparável de uma experiência que o saber faz de si mesmo enquanto saber diferenciado: o saber participa desse momento em que o social está em busca da sua inteligibilidade. Como não há a representação de um poder que detém o conhecimento sobre o social, então a palavra circula, faz a experiência da sua diferenciação, arrisca-se a colocar tudo sob interrogação, sobretudo aquilo que era tido por tabu. É nesse sentido, reafirmamos, que a instituição do social é inseparável dessa experiência em que o saber é ciente da sua diferenciação, uma vez que ele não é mais prerrogativa do poder, ou melhor, uma vez que não emana 
mais do centro do poder ou não é dado previamente pela palavra mítica ou religiosa. $\mathrm{O}$ discurso pode, assim, experimentar poder de discurso, enquanto discurso que participa da instauração da identidade coletiva.

No momento da instituição, vale acrescentar, as balizas entre o certo e o errado, o justo e o injusto, o lícito e o ilícito, o permitido e o proibido, o bom e o mau não estão delimitadas, mas estão em jogo, expostas a uma indeterminação radical. Tais momentos emergem no social abrindo fendas, proporcionando uma abertura no espaço e no tempo, pela qual a sociedade tem a ocasião de se repensar e se transformar. Ora, o que faz o discurso ideológico sobre esse momento de indeterminação e abertura? Ele busca livrar a sociedade desse movimento efervescente, em que a dúvida e a incerteza pesam em toda parte, de modo a reconduzir a indeterminação ao postulado de um saber determinado. A ideologia irrompe para deter a historicidade do social, apossando-se, em toda parte, "dos signos da criatividade histórica, do que não tem nome, do que se esconde da ação de um poder, do que se desconjunta através das aventuras dispersas da socialização - signos daquilo que torna uma sociedade, ou a humanidade como tal, estranha a si mesma" (Lefort, 1979a, p. 315).

A ideologia está, assim, na dependência do discurso instituinte, do discurso que o social busca elaborar sobre si para se tornar inteligível a si mesmo. Ela persegue as marcas do novo e daquilo que contradiz o estabelecido para minar sua força de instituição. É por isso que a ideologia não pode permitir a latência do discurso social, a sua indeterminação, a dúvida, ou melhor, não pode permitir as brechas que se abrem historicamente para relançar os fundamentos da sociedade em questão, numa direção transformadora. É nesse sentido, poderíamos dizer, que a ideologia não é apenas a-histórica (na medida em que negaria a historicidade das ideias e ações, por exemplo), mas principalmente anti-histórica (na medida em que visa frear o movimento de instituição e transformação da história, detendo o movimento do novo e do acontecimento). Não é à toa que Lefort compreende a ideologia, num sentido amplo, como a reposição da lógica da "sociedade sem história" na sociedade histórica.

Num sentido amplo, a ideologia é pensada por Lefort como o desejo de restituição da determinação, da certeza, da suspensão do movimento de interrogação que inaugura o processo moderno de instituição do social. Argumentando no sentido de mostrar o impulso do discurso ideológico como impulso pela determinação, afirmação, abstração e generalização, Lefort enfim sintetiza: a ideologia é

Um discurso segundo que segue as linhas do discurso instituinte, que não se conhece, e que, sob seu efeito, tenta simular um saber geral sobre o real como tal. Portanto, discurso que se desenvolve no modo de afirmação, da determinação, da generalização, da redução das diferenças, da 
exterioridade face ao seu objeto - e, enquanto tal, implicando sempre num ponto de vista de poder - que carrega a garantia de uma ordem virtual e tende rumo ao anonimato para testemunhar uma verdade impressa nas coisas (Ibid.).

Além de colocar o nascimento da ideologia na esteira de uma mudança política referente ao lugar do poder, o que já assinala uma diferença sensível em relação a Marx, Lefort confere um estatuto diferente à divisão social. A divisão não é mais, como em Marx, a divisão do trabalho em cujo fundamento encontra-se a divisão natural segundo o gênero, como também não é apenas a divisão das classes empiricamente determinada. A divisão social, com Lefort, é tratada sob dois ângulos complementares: num primeiro sentido, ela é concebida como divisão da sociedade a si mesma. Sob essa perspectiva, Lefort busca conferir à divisão social um estatuto e uma profundidade de caráter ontológico, na medida em que ela se refere ao ser da sociedade, à divisão da sociedade consigo mesma, à distância inultrapassável que ela mantém em relação a si mesma. Divisão da sociedade a si significa, por conseguinte, que é impossível que a sociedade coincida consigo mesma, alcançando definitivamente sua unidade e sua identidade. A divisão não é um acidente empírico destinada à conciliação, mas é constitutiva do modo de ser da sociedade, ou seja, é divisão originária. A sociedade somente pode existir pela e na divisão. A divisão social, nesse primeiro registro em que Lefort a concebe, expõe o caráter inacabado de uma sociedade e a lança num trabalho infinito sobre si mesma na busca de sua identidade e de sua unidade, impossíveis, no entanto, de se apanhar definitivamente ou se efetivar no real. Numa palavra, a divisão, para Lefort, é de natureza simbólica e aparece enquanto tal quando a comunidade política deixa de localizar a sua origem, a sua unidade e o princípio de sua organização no corpo do governante.

Num segundo sentido, digamos, interno à sociedade, a divisão social não é pensada por Lefort como divisão entre ricos e pobres, como também não é a divisão empírica e economicamente fundada entre as classes sociais antagonistas. Herança clara da meditação sobre a obra de Maquiavel, Lefort ressignifica o estatuto da divisão civil, analisando-a agora muito mais em função da dominação política, inserida no campo dos desejos políticos assimétricos, ou seja, desejo de dominação, de um lado, e recusa da opressão, de outro. Apropriando-se da descoberta de uma lógica de funcionamento de toda cidade, que se funda na divisão dos humores, Lefort coloca também a divisão civil e o conflito na base da constituição política e da produção de leis e direitos, enfim, daquilo que poderíamos chamar universais políticos. Donde o novo significado que o conflito passa a ter na filosofia política de Lefort; é no conflito, devido ao seu caráter politicamente produtivo - em muito diferente das facções, dos sectos ou dos grupos de interesse - que reside 
o motor de produção da ordem política. ${ }^{\text {II }}$

Se, por um lado, a divisão é a marca de historicidade, uma vez que relança a sociedade num trabalho infinito para perseguir sua identidade, se, por outro, ela é inultrapassável, isto é, uma sociedade nunca detém definitivamente sua identidade e abole a distância a si mesma, sendo incapaz de superar sua divisão interna e abolir a divisão dominantes-dominados que constitui o social, isso não quer dizer que a divisão social opere perfeitamente no sentido de salvaguardar a liberdade política sem maiores resistências. Se assim fosse, não existiriam os diversos fenômenos da ideologia, cuja tarefa principal é dissimular a divisão social, impedindo que ela exerça seus efeitos históricos e transformadores. E, sobretudo, não teríamos, no extremo da denegação da divisão, a formação de regimes totalitários, que se engendram negando a divisão social sob todos os aspectos, preenchendo o lugar vazio do poder e instituindo a figura do Povo-Um.

Da mesma maneira que podemos reconhecer inúmeras e renovadas tentativas de encobrir e negar a divisão social, somos impedidos de pensar a superação da divisão como meio de pôr fim à dominação e à ideologia, como, aliás, Marx havia esboçado. É nesse sentido, dirá Lefort, que falamos da ideologia sempre no plural, ou seja, de ideologias, pois esse fenômeno, congênito à instauração da modernidade, do discurso propriamente político e da aparição do campo social a si, esse fenômeno - dizíamos — segue se rearticulando indefinidamente, assumindo novas figuras quando se depara com o limite de suas contradições. Insuperável, a ideologia se rearticula passando por transformaçoes infinitas e imprevisíveis, inaugurando uma história própria cujo desenrolar não prevê nenhum término. É nesse sentido que Lefort introduz uma novidade na intepretação da ideologia, a saber, a compreensão da passagem da ideologia burguesa à sua forma totalitária e, desta, à ideologia invisível, que, embora apareça esboçada, possui grande fecundidade teórica, na medida em que designa a nova forma do imaginário social das democracias ocidentais, engendrada pelos novos meios de comunicação para construir uma imagem da relação social inédita que nega as divisóes sociais por meio da simulação de um espaço de encenação da fala, no qual a palavra circularia livremente, dando a ilusão de uma horizontalidade das relações discursivas e da expansão do direito à palavra.

Ao dizer que com a modernidade é instaurada uma história infinita das ideologias, posto que as tentativas de encobrir a divisão social não cessam, Lefort se distancia de dois outros eixos da análise marxista. Primeiro, se a divisão social

II A reformulação do estatuto da divisão social baseia-se, amplamente, na interpretação que Lefort realizou de Maquiavel em seu livro Le travail de l'œuvre Machiavel (1972), fruto de um estudo concentrado de mais de uma década. Para uma exposição mais concisa dessa nova apreensão da divisão social, herdada da reflexão sobre Maquiavel, cf. Lefort, i979b. 
é insuperável porque constitui o modo de ser da sociedade, não há classe social universal portadora da criatividade histórica capaz de superar a contradição capital-trabalho e pôr abaixo o reino da representação ideológica. Segundo, a essa altura de sua trajetória intelectual e política, Lefort não compartilha mais a concepção de uma história que caminha em direção à abolição dos seus conflitos e das formas históricas de dominação, graças à ação revolucionária do proletariado. Assim, ao reinterpretar o funcionamento da ideologia, Lefort altera substancialmente sua compreensão acerca do proletariado como sujeito histórico ao mesmo tempo em que se afasta da ideia marxista de revolução.

Mas, então, o que restaria após essa demolição da arquitetura crítica elaborada por Marx para desvelar as ações da ideologia? De que maneira esse movimento crítico poderá reconduzir a uma revalorização do político e da democracia se, desde já, é afirmada a impossibilidade de superar a ideologia e a dominação, se, desde já, a luta política é vislumbrada sem fim, no duplo sentido do termo, ou seja, sem término e sem a representação de uma razão última a perseguir e a realizar? Para Lefort, longe de lançar no descrédito as categorias do pensamento e da prática política, esse movimento nos abre para a reabilitação de uma concepção muito específica da democracia, na qual sua dimensão simbólica vem desempenhar um papel de contrapeso à ideologia. $\mathrm{Na}$ democracia lefortiana, não há sujeito histórico único e exclusivo que age no sentido de suprimir a totalidade das expressões históricas da dominação; há, ao contrário, sujeitos múltiplos que se organizam aqui e agora, ou seja, em circunstâncias históricas particulares, contra as investidas da dominação; a ação política, em Lefort, é circunstanciada e não pressupõe a ação de uma classe universal que lutaria, em abstrato, contra a dominação universal. Não há revolução no sentido estrito, mas invençōes democráticas, que supōem a ação sempre renovada dos agentes políticos. Não há, por outro lado, o descarte da esfera da representação como esfera simples de dissimulação do real. Há, efetivamente, a defesa de uma dimensão simbólica que emoldura a percepção e a apreensão da realidade pelos sujeitos numa democracia. Ao introduzir o simbólico, como instância distinta a da ideologia e que opera como mediação que nos permite um acesso ao real, Lefort reconfigura toda a apreensão da realidade num regime democrático. Se o simbólico é um vazio eficiente, que se relaciona com o real, a pergunta que se coloca é: como o simbólico atua sobre o real? Ao afirmar que o real não é aquilo que se vê e não se limita à experiência empírica que fazemos dele, podemos nos referir, segundo Lefort, a outra dimensão e reivindicar o poder de ideias, símbolos e direitos para ultrapassar os limites da própria experiência empírica, que se mostra em limites históricos e temporais sempre estreitos.

Lefort nos sugere, assim, que o sentido da nossa realidade não está e não se reduz àquilo que se vê na imediatez da experiência histórica e social, tal como a 
particularidade da lei, a instrumentalidade do poder, em suma, o poder reduzido a instrumento de dominação; ele nos sugere, em contrapartida, que podemos nos relacionar com a realidade por meio de símbolos: a lei como símbolo, os direitos do homem (liberdade de pensamento, de ação e de organização, direito à resistência à opressão) como símbolos, os valores sociais (solidariedade, confiança, justiça) como símbolos. É por acreditar no poder efetivo dos símbolos políticos que Lefort recusa descartá-los, como faz Marx, julgando-os meros produtos da ideologia dominante. Ao contrário, Lefort enxerga nesses símbolos não o simples produto disfarçado da dominação, mas a referência a valores universais que nos permitem mover, transformar, alargar os limites da realidade história presente e os limites do possível. ${ }^{\mathrm{I}}$

O simbólico, instância que emerge da crítica que Lefort endereça à concepção marxiana da ideologia, mostra-se à distância da ideologia e desponta, é verdade, enquanto um conjunto de referenciais vazios, tais como as noçóes de Liberdade e Igualdade. O simbólico é, sem dúvida, um vazio, cavidade desprovida de substância, mas é um vazio eficiente: ele faz algo, abre e sustenta um campo de ação, conferindo-lhe um poder legítimo de instituição capaz de pôr em questão aquilo que se encontra instituído. É o caso clássico da ideia de liberdade: que substância teria? Quem poderia definir seu significado último e apropriar-se dele? Que força tem senão a força simbólica de alicerçar uma luta e dar sentido à recusa da opressão? E quem poderia, com razão, reduzir sua importância, acusá-la de ser meramente uma ideia burguesa? Enfatizar e revalorar a dimensão simbólica, esquecida por Marx - eis o caminho que Lefort visa abrir. Daí toda a importância de complicar o esquema marxiano, apoiado na distinção entre o real e o imaginário, abrir uma fenda no domínio da ideologia e permitir alguma distinção com o simbólico, apostando no seu sentido interrogativo e instituinte, apostando, enfim, na capacidade que a dimensão simbólica da sociedade democrática tem de nos lançar numa nova relação com os demais sujeitos e com a própria realidade

I2 Após atentar a esse novo enquadramento que Lefort confere à interpretação da ideologia, certamente seremos capazes de apreender com outro alcance a discussão que Lefort realiza no célebre ensaio "Direitos do homem e política", no qual, tomando novamente distância crítica de Marx, nega a redução desses direitos à mera função ideológica na sociedade de classes e defende, em contrapartida, o seu caráter simbólico, instituinte, transformador. Colocados como referência última da sociedade democrática, os direitos do homem fundam uma dinâmica ininterrupta de criação de novos direitos e sustentam novas lutas, específicas e imprevisíveis, que visam criar espaços universais em que singularidades possam ser acolhidas e protegidas: pensemos, por exemplo, na luta específica conduzida por mulheres, homossexuais, negros, trabalhadores, sem terra, sem teto, minorias em geral. É o simbólico - sob a forma da linguagem do direito, da liberdade, da igualdade e da recusa da opressão - operando na sustentação das lutas democráticas para além da representação ideológica a que essas noções podem se prestam. Cf. Lefort, 201 I. 
histórica. Se isto parece pouco, mero produto de um marxismo desiludido com a ideia de revolução, que se meça a dimensão dos campos de luta que se abriram e se abrem na história recente em nome da extensão e da efetivação de direitos civis e políticos fundamentais.

\section{Referências}

Abensour, Miguel (1993). "Réfléxions sur les deux interprétations du totalitarisme chez C. Lefort", In Claude Habib \& Claude Mouchard, La démocratie à l'oeuvre: autour de Claude Lefort, Turriers: Esprit, pp. 79-136.

FlynN, Bernard (20I2). La philosophie politique de Claude Lefort, Paris: Belin.

Lefort, Claude (I979a). "Esboço de uma gênese da ideologia nas sociedades modernas", In As formas da história: ensaios de antropologia política. São Paulo: Brasiliense, pp. 245-345.

Lefort, Claude (I979b). "Maquiavel: a dimensão econômica do político", In As formas da história: ensaios de antropologia política, São Paulo, Brasiliense, pp. I4I-I54.

Lefort, Claude (1979c). "O nascimento da ideologia e do humanismo", In As formas da história: ensaios de antropologia política. São Paulo: Brasiliense, pp. 25I-294.

Lefort, Claude (20II). "Direitos do homem e política", In A invenção democrática: limites da dominação totalitária, Belo Horizonte: Autêntica, pp. 59-86.

Lefort, Claude (1979c). Éléments d'une critique de la bureaucratie, $2^{\mathrm{ème}}$ ed., Paris: Gallimard.

MarX, Karl; Engels, Friedrich (2007). A ideologia alemã: crítica da mais recente filosofia alemã em seus representantes Feuerbach, B. Bauer e Stirner, e do socialismo alemão em seus diferentes profetas (1845-1846), São Paulo: Boitempo. 